\title{
Subterranean Currents: Research and the Radical Imagination in the Age of Austerity
}

\begin{abstract}
ALEX KHASNABISH
Mount Saint Vincent University, Canada

ABSTRACT Against a backdrop of austerity, securitization, and the rampant enclosure of public spaces and democratic processes including the university and scholarship, this article critically explores what prefigurative engaged research-research capable of not simply documenting what is but contributing to struggles for social justice and social change - might look like, what it can contribute, and what its limitations are. Beyond familiar calls for a "public" or "applied" social science and drawing on a two-year-long project focused on radical social movements and the radical imagination in Halifax, Nova Scotia, Canada, this article explores what politicallyengaged social science research might offer to social justice struggles aiming to construct a more just, democratic, dignified, liberated, and peaceful world.
\end{abstract}

For the majority world - for everyone outside the enclaves of privilege located disproportionately, though by no means exclusively, in the global North-globalized neoliberal capitalism and its logic of accumulation by dispossession (Harvey, 2003; McNally, 2011) has been only the most recent chapter in a more-than-five-century history of genocide, colonialism, and imperialism. In the global North, the social violence unleashed by neoliberalism (increasingly precarious or nonexistent work, entrenched and deepening inequality and immiseration, the evisceration of public services, the enclosure of public space, the augmentation of the state's repressive apparatuses alongside the withering of its commitments to even the most basic elements of social welfare) has meant a low-intensity war declared against actors, institutions, and practices identified as contrary to this neoliberal order. In this context, the university has become a key site of struggle both in terms of what a remade academy could offer to capital (research 
and development, resources, expertise) and what it does not (an imperfect space of critical and free inquiry), a struggle that has manifested within the academy along clearly disciplinary lines. This is not a lament for the by-gone days of the liberal university imagined as a place of free inquiry, democratic participation, and critical discussion. Indeed, we would do well to remember that dominant institutions like the university have always been tied to the production and reproduction of the social order in which they are enmeshed (Wallerstein, 1996). Rather, at issue is how institutions like the university and academic disciplines function to either facilitate the construction of more just, democratic, egalitarian, and liberated socio-political and economic orders or how they work to entrench, defend, and deepen power, privilege, and inequality.

Knowledge work, particularly in its academic disciplinary formation, has often lived a complex and frequently compromised relationship with systems of power and privilege (Lal, 2002; L. Smith, 1999; Wallerstein, 1996). For example, as someone trained in the anthropological tradition, I am bound up in a discipline shaped by powerful interests, specifically imperial and colonial ambitions. It is not my intention here to delve deeply into this troubled history and anthropology's relationship to empire-building, colonization, and genocide, nor do I want to suggest that this is all that anthropology is or could be. Rather than dwelling on the profoundly compromised history of anthropological knowledge production, I want to acknowledge this history and use it as a starting point for further exploration. Indeed, if this history is troubling - as it should be - the ongoing weaponization of anthropology and other disciplines should be equally so and certainly be more cause for action and intervention today (Network of Concerned Anthropologists, 2009; Price, 2011). Of course, cultural knowledge has always been seen by occupying forces as central to realizing dreams of domination and exploitation, but this kind of knowledge is now seen as absolutely central as elites confront unconventional challenges to the status quo with the aim of achieving "full spectrum domination"-control over the production and reproduction of social life itself - rather than success or failure measured in conventional battlefield terms (Hardt \& Negri, 2004).

In the face of concerted attacks on critical thought and independent inquiry which have only deepened under the banner of "austerity" unfurled in the wake of the 2007 financial crisis, some social researchers embedded in the increasingly neoliberal university have sought to render service to corporate, political, and economic elites and so secure their own positions. Instead of shedding light on the nature and causes of social violence and inequality or the movements aiming to challenge them, research ensconced within the repressive apparatus of the neoliberal state facilitates the repression of struggles and defends established systems of power, privilege, and authority (Hedges, 2010). Rather than seeking accolades, security, or relevance by offering up social research in the service of empire, reloaded of course for the $21^{\text {st }}$ century, we would do well to consider what engaged, critical social science research might offer to living struggles for social justice. Without 
trying to speak for or give direction to movements or to merely archive them and thus speak for and about them as we accumulate academic capital, what can the engaged social researcher contribute to efforts to confront the entrenched and deepening violence, inequality, and injustice that continue to characterize so many people's contemporary social realities? In what follows, I explore what engaged social science research might offer to struggles for social change and the construction of a more just, democratic, dignified, liberated, and peaceful world. Drawing on a two-year-long project focused on radical social movements and the radical imagination in Halifax, Nova Scotia, Canada, I attempt to chart, albeit in a preliminary and incomplete way, what prefigurative engaged research - that is, social research capable not simply of documenting what is but of participating in collectively bringing something into being - might look like and what it can offer.

\section{Radical Imagination, Method, and Prefiguration}

In August 2010, funded by a standard research grant from the Social Sciences and Humanities Research Council of Canada, a four-person research team consisting of two research assistants from the local activist community, my project co-director, and myself began "The Radial Imagination: A Research Project About Movements, Social Change and the Future." From its earliest planning stages, my co-director and I conceived of the project as an explicit attempt to "convoke" the radical imagination - that is, to call something which is not yet fully present into being-in collaboration with activists self-identifying as "radical" in Halifax, Nova Scotia, Canada. From the perspective of our collective project, the term "radical" names movements or approaches that understand the social problems that concern them to be irresolvable within the current political system and so seek systemic change. In particular, both as researchers and political actors, we are interested in radical social movements that have emerged in the wake of the so-called "antiglobalization movement" and that stress values of participatory democracy, radical equality, and anti-oppression in pursuit of social, economic, and ecological justice (Day, 2005; Graeber, 2009; Juris, 2008; Khasnabish, 2008; Maeckelbergh, 2009; Sitrin, 2012; Wood, 2012). As for the radical imagination - the capacity to project how the world might be otherwise-we have argued (Haiven \& Khasnabish, 2010; Khasnabish \& Haiven, 2012) that the imagination is a collective process rather than an individualized thing, and that its wellspring is not the romanticized and fetishized image of the genius-at-work but communities and collectivities as they work their way through the world.

The radical imagination, a term which is seemingly ubiquitous in its invocation today but almost nowhere critically defined, helps us frame the way radical social movements and those who constitute them seek to refashion the space of the political by stressing radical notions of democracy, responsibility, participation, and a politics of the act over dominant liberal paradigms of a 
politics of representation and demand (Day, 2005; Solnit, 2004). Historian Ian McKay (2005) has called such radical political initiatives "experiments in living otherwise"-social laboratories for the generation of alternative relationships, subjectivities, institutions, and practices that prefigure the world these movements seek to build (Conway, 2004). "Prefigurative politics" refers to the general shift in emphasis away from attempts to seize the state apparatus or influence existing socio-political systems and toward the construction of alternative futures in line with the aspirations animating social justice struggles (Holloway, 2002a). The politics of prefiguration that are so central to many contemporary forms of radicalism can be traced to peace, queer, anti-racist, student, feminist, and ecological struggles (the socalled "new social movements") that emerged in the wake of World War II (Bagguley, 1992; Epstein, 1991; Melucci, 1985; Polletta, 2002; Touraine, 1988). These struggles focused not only on influencing dominant political, social, and economic institutions but on the transformation of the production of everyday life itself (Epstein, 1991; Katsiaficas, 2006; Polletta, 2002). Examples of such prefigurative struggles include, but are in no way limited to, alternative education initiatives (Day, De Peuter, \& Coté, 2007; Haworth, 2012), migrant justice collectives (Lowry \& Nyers, 2003; Walia, 2013), squats and politicized housing cooperatives (Bockmeyer, 2003; Katsiaficas, 2006; Wachsmuth \& Pasternak, 2008), direct action affinity groups and networks (Graeber, 2009; Juris, 2008), indigenous solidarity groups (Keefer, 2007), and radical attempts to build relations of solidarity rather than charity across borders (Featherstone, 2012; Katsiaficas, 1987; Khasnabish, 2008).

Our research-based intervention into the field of radical imagination and radical politics seeks to address a central problem identified by recent scholarship on radical social movements in North America and elsewhere which has demonstrated that established methods and theories are insufficient to address the rise of a politics of prefiguration (Day, 2005; Holloway, 2002b; Juris \& Khasnabish, 2013; Katsiaficas, 2006; Polletta, 2002; Selbin, 2010). In our project, we have argued that the radical imagination defines not something radical social movements like those listed above have but something they $d o$. Without visions of how the world might be different than it is, social change action lacks the force necessary to animate it. The radical imagination is the spark that animates them and exists only in the context of the dialogic encounters between actors. Unlike ideology which is a fairly coherent, structured, and elaborated system of interlocking ideas about the world and one's place in it, the radical imagination can be thought of as a shifting horizon of possibility that, like all horizons, recedes as we walk toward it. As a result, the study of the radical imagination necessitates the crafting of new methodologies capable of participating in this process, not merely describing it from afar.

But why ground this project in Halifax, Nova Scotia as opposed to any of the large, cosmopolitan urban centres that have served as backdrops for many of the summit spectacles so characteristic of the heyday of the alterglobalization movement? In the first place, we chose Halifax because it is 
where we live. Rather than seeking the most exotic and dramatic locale for our research, we have sought instead to ground our work in our own space and place and to try to contribute something to radical social movements and the fabric of struggle from our own location as engaged researchers. Beyond this, there are several other factors that make Halifax an ideal site for our project. A mid-sized city of approximately 300,000 , Halifax is a regional military, administrative, and economic hub on the periphery of the Canadian state. In locating this project in Halifax, we sought to both mobilize our pre-existing knowledge of the city and its activist history as well as to shed light on a unique location whose radical social movement fabric was - and, at the time of this writing, still is - in the process of reconstituting itself. A formerly prominent colonial centre, in recent years Halifax has found itself marginalized with respect to national and global politics and economics. Measured by almost any index (population, economic growth, immigration rates, GDP, etc.) Halifax is by no means a substantial influence on national, let alone global affairs. And yet, in an age of globalization, even the margins are traversed by lines of power and globalizing economic, institutional, cultural, military, and political flows (Appadurai, 1996).

As an example of this, in June 2007 Halifax played host to the Atlantica summit of Canadian and US political and economic leaders eager to transform the north-eastern seaboard into a free trade zone. Complete with a race-tothe-bottom for labour and environmental standards, the goal of the summit was to lay the groundwork to turn the region into a "gateway" for goods produced in Asia to enter the continental United States while simultaneously accelerating energy exports to the US (Sinclair \& Jacobs, 2007). This summit was an obvious target for radical activists in the Halifax area and beyond given the neoliberal paradigm it exemplified and protests were planned along the lines of the convergence model that had become so prominent through the alter-globalization movement. Despite the appropriateness of the target and the established protest repertoire, the protests themselves resulted in what almost all participants and observers report to be an unqualified disaster. Entrenched disagreements over protest tactics and inadequate collective participation in the protest planning process led to a poisonous polarization between more conventional protesters and a "black bloc" engaged in clashes with police. Veteran activists note that the event ruptured relations of trust and cooperation that had been built over decades, toxifying the local ecology of radical activism. Fragmentation and sectarianism followed closely on the heels of this fracturing of the field of radical politics. At the same time, this situation affords us a unique opportunity to study the radical imagination in action as radical movements seek to reconstitute themselves in a relatively small socio-political space.

Social movements have long been objects of social scientific inquiry. Particularly from the 1960s on, social movement scholarship has, at its best, shed important light on how, why, and with what consequences people have organized themselves to try to achieve some kind of social change outside of formal political structures and processes. In contradistinction to earlier 
generations of sociological work which cast social movements as little more than irrational, unwashed mobs that functioned, at best, as "escape valves" maintaining the equilibrium of the status quo, social movement research since the 1960s has taken social movement action seriously and sought to understand these collective actors not only in terms of the structural factors affecting their lifespan (Tarrow, 1988) but also their capacity to mobilize resources (Zald \& McCarthy, 1979), take advantage of openings in the political system (Meyer, 2004), advance claims and frame issues (Benford \& Snow, 2000), deploy consciousness, emotion, biography, and culture as social change tools (Goodwin, Jasper, \& Polletta, 2001; Jasper, 1999; Mansbridge \& Morris, 2001), and network their efforts across national borders (Bandy \& Smith, 2005; Della Porta, Kriesi, \& Rucht, 2009; Keck \& Sikkink, 1998; J. Smith, 2008). This is all important and insightful work but the bulk of it also positions social movements as political actors vying for influence and leverage within the established political system, rendering it insufficient for the study of contemporary radical tendencies whose aspirations are a direct challenge to the very form of the socio-political itself and which are embodied by a variety of unconventional actors outside of political parties and NGOs.

In response to the inability of more conventional methodologies to perceive and make sense of radical challenges to the status quo and attempts at cultivating alternatives to it, in the Radical Imagination Project we have turned to methods grounded in ethnography and participant-action research to develop an approach better attuned to these new radical tendencies (Conway, 2004; Graeber, 2009; Juris \& Khasnabish, 2013; Juris, 2008; Khasnabish, 2008; Maeckelbergh, 2009; Sitrin, 2012). Engaging social movements as living entities produced and reproduced through the interactions of those individuals and groups that constitute them, as well as through the interventions they undertake in relation to the wider social world, demands a research methodology that takes seriously and treats as primary living social realities rather than approaches that offer diagnostics of movements, mapping them onto a political landscape delimited by dominant socio-political and economic institutions, powerful actors, and their attendant ontologies and epistemologies. There are important threads within the tremendously broad ethnographic methodological field from which to draw in order to achieve these ends. Understood not just as a set of qualitative research methods, ethnography is a mode of analysis and writing that aims via "thick description" to communicate complex social realities to broader audiences. This attention to the lived is the crux of ethnography's analytical utility as well as the basis for its potential political significance. In this regard, it should come as no surprise that ethnographers have been compelled - often by the very people with whom they have worked - to address the politics of knowledge production if for no other reason than because ethnographic work is grounded in the lives of others. Critiques of ethnographic research are certainly nothing new, having been raised by feminists, indigenous peoples, and anti-colonial struggles (L. Smith, 1999), among others, going back decades. Within anthropological circles, it was the "crisis of representation" in the mid-1980s 
that shook objectivist and positivist approaches to ethnography (Clifford \& Marcus, 1986), advancing the banal but fundamental observation that every act of representation is also an act of power and naming anthropology's historical imbrication with systems of power and domination.

Confronting these challenges, engaged researchers have plumbed the political potential of ethnography by exploring it as a form of socio-political and cultural intervention. Indeed, an emerging body of work produced by politically engaged scholars testifies to the utility of ethnography as a research method particularly well-suited to research with social movements. This is due in large part to the fact that as a methodology it insists on the explicit positioning of the researcher in relation to her research "field" and those who occupy it. Even for researchers who seek to eschew the political, this positioning is unavoidable. This self-reflexivity and the willingness to be a part of and, potentially, to be transformed by the act of engaged research is something that is all too often absent from more conventional investigations of social movements. Additionally, because of its focus on lived realities, ethnographic methods are particularly well-placed to facilitate a serious exploration of social movements as producers of knowledge rather than simply objects of research (Conway, 2004; Juris \& Khasnabish, 2013; Maeckelbergh, 2009; Sitrin, 2012). David Graeber has gone so far as to suggest that ethnography could be a model for the "would-be nonvanguardist revolutionary intellectual" because it offers the possibility "of teasing out the tacit logic or principles underlying certain forms of radical practice, and then, not only offering the analysis back to those communities, but using them to formulate new visions" (2007, p. 310). Terming it "militant ethnography," Jeffrey Juris has articulated a similar vision of radicalized ethnographic practice which refuses the valourization of "objective distance" and the tendency within the academy to treat social life as an object to decode (2008, p. 20). Instead, Juris argues that in order "to grasp the concrete logic generating specific practices, one has to become an active participant" and within the context of social movements this means participating in and contributing to the work of these movements themselves $(2008$, p. 20).

Juris $(2007,2008)$ describes a militant ethnographer as someone who not only sympathizes with the struggles of those with whom she works but who is committed to being directly involved in a given struggle over the long term by taking on work, responsibilities, and risks borne by activists themselves. This does not mean that the militant ethnographer only produces tactical or strategic analysis for the movement in which she is involved; indeed, such an ethnographer should produce engaged research capable of speaking to a variety of constituencies. The practice of militant ethnography also does not imply an erasure of issues of power and privilege or the abandonment of commitments to rigorous research methods; rather, its deep logic is grounded in the premise that taking sides is something everyone is already doing and, in the context of social justice struggles, rather than being a violation of ethical research, is directly a part of it. But while militant ethnography resonates with the methodological approach we advance in the Halifax 
Radical Imagination Project, it remains a posture whereby researchers tend to disappear into movements. Our own approach tries instead to mobilize the weird autonomy-compromised, privileged, imperfect, unjust, but nonetheless potentially productive - of the academic vocation in order to help collectively craft a space and a process capable of calling something into being which is not yet fully present (Khasnabish \& Haiven, 2012). In the absence of sustained, radicalized mass movements (the surprising emergence of the Occupy movement notwithstanding), in the midst of concerted attacks by political and economic elites on hard-won social justice gains, and faced with the waning of previously compelling imaginations of radical political possibility, our research-based intervention in the field of radical imagination must do more than explore fetishized invocations of it, it must participate in the process of collectively calling it into being.

\section{Convoking the Radical Imagination}

The Halifax Radical Imagination Project goes further than most ethnographic accounts of social movement activism in the sense that it seeks not merely to observe but to convoke the radical imagination, to catalyze a public dialogue between those who make up radical social struggles and understand radical imagination as a dialogic process. We have sought to achieve this through several different project stages. The team's active research phase began in September 2010 and was constituted by one-on-one interviews and focus groups, supplemented by our attendance at movement events and a selfreflexive process involving regular team debriefings. Project outreach was carried out by placing advertisements in local alternative media sources (print, radio, and on-line), postering and pamphleting in public spaces, using preexisting research and activist connections with groups and individuals, and word-of-mouth participant recruitment. Since September 2010, we have conducted nearly thirty one-on-one in-depth and open-ended interviews with diverse members of the Halifax activist community. Our participants included student activists, radical publishers and academics, anarchists, trade unionists, feminists, queer activists, punks, Marxists of various stripes, independent media makers, local food and climate justice activists, and members of direct action collectives. Focused on getting research participants to reflect on their own political biographies, notable moments of radicalization, perceptions of opportunities and barriers to radical social transformation, and visions of the future, these interviews aimed to collect an archive of radical activism in Halifax at a particularly crucial time marked, on the one hand, by movement reconstitution and, on the other, by an ascendant Right wing agenda. We believe this kind of archive has utility not only for social movement scholars but for future generations of activists and organizers, particularly given the absence in so many grassroots, non-institutional movements of a place or process to intentionally curate the collective memory of struggle.

The interview stage of this project constituted our initial attempt to provoke 
a wider dialogue amongst the activist community in Halifax. Flowing from the interview phase were two critical and interrelated processes. The first was constructing our project website (radicalimagination.org), an interactive space serving as a digital archive of thematically-organized interview clips from consenting interviewees as well as hosting project publications and other outcomes (including an hour-long audio documentary) and providing up-to-date information to participants and the broader public about ongoing project events. At the time of this writing both the website and the audio documentary are still in the final stages of production but both are aimed at expanding the dialogic process of convoking the radical imagination we initiated through our research in Halifax. We will strive to disseminate the audio documentary more broadly once it is completed, particularly via activist and other independent media.

The second process emerging from the interview stage was the organization/ planning/hosting of a series of three events we configured as "Dialogues on the Radical Imagination" held in the winter and spring of 2011. The Dialogues were free events, held in a community rather than academic space, and open not only to project participants but the broader public. Rather than simply being a forum for the research team to present our analysis to the community, we structured the Dialogues in a way that foregrounded our project participants and positioned the research team as facilitators. Each Dialogue session was initiated by an invited panel of project participants who took turns offering short (generally 5-10 minutes) and often provocative statements based on personal experiences of organizing and activism that served as springboards for moderated, open discussion amongst project participants and members of the broader community. Lasting two hours each, these Dialogues orbited around three key problematics: building resistance and alternatives in an age of austerity; the relationship between anti-capitalism and struggles against other structural oppressions; and the question of how we organize effectively for social change. The objective of these sessions, from the perspective of the research team, was not to "solve" these complex issues or chart a singular way forward for radical Leftists in Halifax but to open a space and a process where it could be possible to safely-though not necessarily comfortably or in ways free of conflict - explore these contested and diverse terrains. These Dialogues, in turn, served as a gateway into the project's final stage (the Radical Imagination Speaker Series) which involved inviting speakers with experience in a variety of radical struggles from outside of the Halifax context to participate in public talks followed by engaged, critical discussion sessions. In this final stage, our intention was to bring a selection of perspectives and experiences not necessarily found within the local context in order to provide new fuel for the dialogic process of convocation we aimed to stimulate.

What I have sought to provide here is an overview of our attempt to build a research-based intervention capable of participating in social change processes and not just cataloguing them. There will, of course, be much more to say as the research team critically engages not only with the reflections offered by our research participants in interviews, on-line, and 
in public discussions but with our own reflexive analysis along with those of our participants of the process itself. We suspect that at the end of this dialogic process we will have many more questions than answers about the radical imagination and its relationship to radical social change struggles. Nevertheless, we are also convinced that our attempt at developing this dialogic, engaged process has already been productive in terms of generating discussion and possibilities concerning the ways engaged research may be used as a radical social change tool, particularly at a time when the horizons of what is socio-politically possible are obscured by crisis, austerity, and an evermore augmented repressive apparatus.

Notably absent from our research process is any description of what the radical imagination looks like at this moment in Halifax. While some may find such an absence curious, this neither surprised nor troubled the research team at all. As I have noted throughout this piece, the radical imagination is not a thing; it is a collective process. Our research intervention into the field of social justice struggle in Halifax aimed not to catalogue the characteristics of the radical imagination of individuals or collectives but to provide a new space and process capable of offering opportunities to those engaged in radical social justice struggles in which to consider in an open, expansive, and non-sectarian way where their struggles have come from, where they are now, and how they might move forward. Elsewhere, we have discussed how one of our key research outcomes was the realization, derived largely from our interview process and a key question we asked each participant about what it would mean to "win" (Turbulence Collective, 2010), that movements do not spend their lives occupying the airy heights of victory or mired in the depths of defeat but in the "hiatus"-the everyday, unromantic space between success and failure that is the space of social reproduction and persistence (Haiven \& Khasnabish, 2013). Our research was therefore not an attempt to catalogue movement wins and losses or to help resolve tactical or strategic debates or to offer an analysis of a specific movement milieu at a particular moment in time, but to explore how research mobilized from the unjustly quasi-autonomous and privileged location of the university might assist movements in learning how best to make use of and dwell within this hiatus.

It is our conviction that the hiatus between success and failure is the vital space of daily life (indeed, as each of us probably intimately understands, it is where we as individuals spend most of our lives) and, as such, it is the space in which movements and those who constitute them are produced and reproduced as living social entities. Marxist-feminist scholars and activists such as Maria Mies (1986) and Silvia Federici (2003, 2012) have demonstrated the centrality of the work of (feminized, invisibilized, unremunerated) social reproduction - that labour that brings labour power into existence and which nurtures and sustains it - not only to capitalist accumulation but to the forms of social life upon which we collectively depend. Social movements are, therefore, also sites of social reproduction, and the ways in which this labour is carried out and the ends to which it is directed (what kinds of social spaces and subjectivities it produces) are perhaps all the more significant when we 
think about radical movements as sites of prefiguration. The reproduction of systems of oppression and exploitation within movements is a deeply troubling dynamic commented upon by numerous scholars and activists (Bishop, 2002; Featherstone, 2012; Graeber, 2009; Martinez, 2000; Mohanty, 2003; Osterweil, 2010; Polletta, 2002; Walia, 2013). While the forces propelling this internalization of systemic injustice are complex, movements have often deferred addressing the perpetuation of oppression within their own spaces through recourse to a more "urgent" or "immediate" set of concerns, crises, or struggles (Bishop, 2002; Mies, 1986). Movements and their participants often claim they lack the time and space necessary to deal with systematic oppressions and the perpetuation of injustices within their own ranks in the face of a multitude of external crises demanding their urgent attention. This kind of rationalization, one we encountered not infrequently in our own research in Halifax, ultimately endlessly postpones the work of coming to terms with these poisonous dynamics and perpetuates the very violence and injustices social justice movements purport to oppose.

Without claiming that our research intervention successfully resolved this vexing problem in the radical milieu in Halifax, our dialogic, convocatory method furnished tools and a context capable of making time for activists and organizers to confront and collectively work through such everyday realities. While our research team was, collectively, averse to conceptualizing research only or even primarily as a form of "radical therapy," we were nonetheless regularly struck by and remain convinced of the fact that university-based research with social movements undertaken in a spirit of solidarity is capable of offering opportunities that movements and those who comprise them cannot or do not offer themselves. Rather than operationalizing and cataloguing movements' political efficacy or lack thereof and so reinforcing and reproducing conventional notions of "success" and "failure," our research led us to problematize notions of what counts as "success" and "failure" for solidaristic social movement research and to ask honest questions about what we as engaged researchers can offer. The result was not a disavowal of the hiatus between success and failure either for movements or those who study them; instead, it highlighted the importance of devising strategies of dwelling well in the hiatus and seeking to understand and intervene in it as the space and time of movement reproduction.

\section{Critical reflections}

There are some important insights to be drawn from the Radical Imagination Project and its process. First, an admission: nothing in our research at the time gave us even a hint of the emergence of the Occupy movement beginning in September 2011. Occupy came to Halifax in October 2011 with a lively occupation of the Grand Parade grounds in the heart of the city's downtown core and involved many people outside of the "usual suspects" in activist terms. That it did not detect the subterranean currents of dissent that 
would ultimately explode into Occupy is not necessarily an indictment of our research but such an absence does and should give us pause and compel us to consider how our own positions as engaged researchers carry with them their own set of assumptions, prejudices, and blindspots. Or perhaps we did not miss this percolating dissent; rather, it is possible that our own initiative simply was not built to intersect with this gestating movement. Further critical reflection on the project, participant feedback, and research team debriefing is necessary before anything definitive can be said on this point.

One vexing question with which we have contended since the earliest stages of this project is whether or not conducting social movement research like this contributes, however unintentionally, to the surveillance, repression, and demobilization of social justice struggles. For example, by curating an on-line archive of activist interview clips, are we not furnishing the state's security apparatus with a searchable database that renders the fabric of radical social change movements visible to those who seek to disrupt them? And yet, we are equally convinced that if systems of violence, exploitation, and repression are to be successfully challenged, it will only be through mass collective action capable of challenging the status quo and building alternatives to it. Engaging people in an accessible, collective, and dialogic way is essential to catalyzing these kinds of movements and convoking the radical imagination essential to inspiring them. This approach, facilitated to varying degrees by the research team, is also methodologically rigorous and robust, providing the framework for critically productive encounters to occur between people committed to a variety of social justice struggles.

Any and all information relating to social justice struggles is prized by those invested in defending the status quo and the interests it serves. Recognizing this, our project has carefully avoided collecting anything that might be considered "operational information" as it relates to activists and their movements. Indeed, the project's focus has always remained squarely on facilitating a collective space and process to convoke the radical imagination with radicals in Halifax rather than collecting information about strategies, tactics, and balance of movement forces. Of course, we have also sought to strictly protect the confidentiality of all our participants and the anonymity of those who have requested it.

None of this makes the risk of our research being co-opted disappear, but it does, at a minimum, build in safeguards that mitigate against it. We remain convinced, as we were at the outset of this project, that having these conversations is now more necessary than ever but only if they truly do contribute to movements and the radical imagination animating them. If not, they are either exercises in academic capital accumulation or group therapy sessions, neither of which meet our identified objectives.

Many participants reported positive outcomes from the project. They found the interview phase useful, providing a rare opportunity to engage in meaningful dialogue about their political biographies, social change commitments, and ideological orientations in an unconventional format not tied to the day-to-day work of their activism. Appreciation was often 
expressed for the archiving of these dialogues through the project (specifically the website) in a way that would be accessible to other activists and the broader public, although this was frequently joined by a wry skepticism that people would actually take the time to read and engage each other's reflections. Others, however, expressed their frustration with the emphasis on "dialogue" and "debate," contending that such practices were overvalued and could even function to obscure profound ideological and personal tensions within the activist community. Some activists simply refused to participate, judging the process from a distance as too disconnected from the pressing issues confronting them in the context of their own social change work or too compromised by its academic location. Still others participated but did so anonymously, some choosing to do so out of a wariness of state surveillance, others out of concern for what they perceived to be a highly judgmental community. While we never expected the project to engage everyone in the activist community in Halifax and we are loathe to read too much into these dynamics without more evidence and further reflection, it is safe to say that, to some extent at least, this unevenness reflects the deep fractures that continue to scar the landscape of racial activism in Halifax and the inability of a process like ours to assist members of this community to work through them.

From a methodological perspective, many participants criticized our recruitment strategy, suggesting that "activism," "radicalism," and social movement participation cannot be limited to those who self-identify as such, noting that such self-identification highlights the voices of those with social privilege. We were also faced with skepticism about the goals of the project itself, with more than a few activists expressing the belief that it was designed, first and foremost, to accumulate academic capital and only secondarily to benefit the community. Some participants challenged the ethical framework guiding the project, claiming that, despite its commitment to engaging primarily anti-hierarchical social movements and the extensive consultation of the activist community during its design phase, it nevertheless lacked formal mechanisms ensuring community direction and oversight.

The Dialogue sessions produced similarly ambivalent outcomes. On a positive note, many participants spoke of appreciating taking part in a collective process aimed at discussing "big" ideas and sharing political experiences, motivations, and commitments in a space they perceived to be neutral. Many agreed that such spaces were relatively rare in their political experience and they also reported being inspired by the sessions. From our perspective as researchers, we were pleased with the relatively high turnout for each session (between thirty and forty in each case) as well as the fact that many returned for all three sessions. But the Dialogue sessions did not escape criticism. For example, some participants with more political experience expressed frustration that the Dialogues did not contribute tangibly or practically to movement strategy or solidarity. On this point, it is worth remembering that forging solidarity and answering tactical or strategic questions were not actually the goals of the sessions or the project. Quite the 
opposite, in fact, was true, as the Dialogues were intended to make differences and disagreements more transparent, lay bare some of the oppressions and injustices internalized within the space of movement reproduction, and stimulate broader collective visions of socio-political possibility. Other criticisms raised concerned the choice of the panelists we invited to initiate each session. Due to reasons ranging from schedule conflicts to lack of interest, our panelists were often less diverse that we had initially imagined, both in terms of their backgrounds and their political positions. For those more experienced politically, the relatively open nature of the Dialogues inhibited their ability to engage one another directly in more sophisticatedand often animated - strategic debates for fear of alienating less seasoned attendees. Compounding this, many of our participants from marginalized constituencies - queer, African-Nova Scotian, and even women-felt that the events' open-ended and lightly-moderated format did not allow for an effective exploration and practice of anti-oppression politics, thus allowing the sessions to be dominated by the familiar cast of privileged characters. This concern was highlighted during the second Dialogue session which aimed to stimulate critical discussion about the intersection of oppression and capitalism and oppression within social movements. While the free-flowing discussion was lively, it rested almost exclusively on the question of capitalist oppression and exploitation and conspicuously avoided the more troublesome and all-too-often submerged issue of movement participants' own behaviours and practices as they relate to the reproduction of systemic oppressions within and outside of movements. This issue came to the fore again in the leadup to the final Dialogue session as issues of sexual aggression, patriarchy, and sexism within the movement were brought up by a number of activists. Many participants felt that the project ought to commit time and resources to assisting the community in working through these dynamics, but we have yet to succeed in crafting an effective, collaborative, and engaging way of doing so. This is a prime illustration of the importance of the space - the hiatusbetween "success" and "failure" that movements so often dwell within and the quotidian work of reproduction that takes place there. Our inability to address in a deeper and more satisfying way the reproduction of oppressive systems within this space does not attest to the impossibility of solidarity research doing so; it only illuminates the importance of the attempt and the limits of our own specific approach.

On the whole, however, the research team has been pleased by the community response to the Radical Imagination Project. While not every activist, organizer, or self-identified radical in Halifax responded to the project with unequivocal enthusiasm, many were excited to take part in it, others saw a qualified utility in it, while for some it was met with disinterest and skepticism. Given that the objectives of the project were never instrumental or tactical, along with our conviction as researchers that the radical imagination is both a subterranean current in collective thought and an everyday manifestation and process, the impact or outcomes of the project are difficult to measure. For those disappointed or frustrated by the fact that we did not 
provide a snapshot of what the radical imagination in Halifax looked like as we wound down our active research phase, we would only remind them that this was never our objective. From the outset we eschewed using research to capture a picture of a specific movement at a specific moment in time and in a specific context and then using this data to generate explanatory models about how movements work, what the relationship between different kinds of social change "variables" is, or how movements "succeed" or "fail." Instead, we sought to mobilize our position and resources as academically-located researchers in order to contribute to processes of knowledge production that movements are already engaged in, albeit in a tremendous diversity of ways and with varying levels of commitment and success. In this respect, we were heartened by the fact that many of those who took part in the Radical Imagination Project reported positive experiences and a broader capacity to collectively envision the future.

And yet, from our perspective as researchers, we also feel that the critical discussions carried on through the phases of this project did not achieve the kinds of innovation, provocation, and inspiration for which we had hoped at the outset. In this sense, the Radical Imagination Project as surveyed here was our first attempt at learning to work in the hiatus - in the everyday spaces between euphoric victories and demoralizing defeats - and something we must refine and refocus as we strive to do so better. In some critical ways our methodological toolbox relied too much on methods steeped in conventional assumptions of "successful" research outcomes (good data, novel outcomes, contributions to "the field") and "successful" social movements (wellestablished, clearly organized, capable of influencing political institutions and decision-makers). Indeed, from our perspective-further confirmed by the reflections provided by participants - the critical, engaged discussions our project aimed to catalyze were largely a rehashing of debates that have taken place amongst radicals at least since the 1960s. Indeed, as the project proceeded, it was the conviction of some members of the research team that despite our committed attempts to create a novel, radicalizing process capable of convoking the imagination, we simply did not push far enough beyond a relatively conventional qualitative research paradigm and so never managed to facilitate a truly collective, dialogic research space or process.

This realization, in part, stimulated the third stage of the project focused on inviting speakers from outside of Halifax to come to the city and give talks on issues relating to the radical imagination and radical social change. The first iteration of the Radical Imagination Speakers Series ran in January 2012 and featured Dr. Glen Coulthard, a member of the Yellowknives Dene First Nation and a professor in the First Nations Studies Program and the Department of Political Science at the University of British Columbia. In two talks over two days - one aimed at a broader community audience, the other held in a university space and attended primarily by academics - Coulthard focused on indigenous struggles, place-based imagination, de-colonization, and the fabric of radical struggle for social change in the context of the Canadian state. The talks stimulated considerable interest and critical discussion amongst 
those who were in attendance. They were also digitally audio recorded and posted to the Halifax Media Co-op website and will ultimately be uploaded to the Radical Imagination Project's website.

The second installment of the series took place in August 2012, featuring Dr. Gary Kinsman, a long-time queer liberation, anti-poverty, and anti-capitalist activist and a professor of sociology at Laurentian University. Kinsman's talk, held in a public library in the historically marginalized but currently gentrifying north end of Halifax, was entitled "Queer liberation history: Resisting capitalism and oppression and challenging the neoliberal queer." Much like Coulthard's talks, Kinsman's presentation generated considerable interest in the activist community and was also digitally recorded for archival purposes.

In November 2012, Max Haiven, my Radical Imagination Project codirector and a professor at the Nova Scotia College of Art and Design, gave a presentation based on his experiences working with Occupy Sandy, the grassroots mutual aid response to superstorm Sandy that devastated the New York metropolitan area in October 2012. Focusing on how the idea and practices of the commons provide a means of resistance to "disaster capitalism" (Klein, 2008), Haiven's presentation generated fruitful dialogue on questions relating to community capacity-building and the role of the state in the age of austerity.

We continued the series in the fall of 2013 when academics and activists Silvia Federici and George Caffentzis visited in October and delivered a series of lectures on the politics of the commons. In these public talks, Federici and Caffentzis discussed themes including women and the global economy, the politics of work under capitalism, anti-debt struggles, and the concepts of the commons and their enclosure. Their visit took place alongside a public celebration of the $250^{\text {th }}$ anniversary of the Halifax Commons, a large parcel of land in the middle of the city, some of which remains public parkland and some of which has been privatized or used to house hospitals and other public institutions. It also occurred alongside the Halifax People's History Conference, a two-day event aimed at presenting the rich and diverse histories of people's struggles for social justice in Nova Scotia. The conference was organized by a non-sectarian, grassroots, anti-capitalist initiative called Solidarity Halifax, a group that emerged as our primary research phase was drawing to a close and that represents an important and exciting initiative in the social movement landscape of Nova Scotia.

In November 2013, the Radical Imagination Project hosted two talks by Harsha Walia, a Vancouver-based feminist and anti-racist organizer and author of Undoing Border Imeprialism (2013) noted for her work with No One is Illegal, a direct action collective committed to migrant justice. Walia's first talk focused on feminism, anti-oppressive practice, and solidarity while the second was about people's movements challenging border imperialism and both generated significant interest within the local social justice community. The following week, the project co-hosted the book launch of Yellow Ribbons: The Militarization of National Identity in Canada (2013) by 
local author and activist A. L. McCready.

We are currently planning further instalments of the Radical Imagination Speakers Series. The feedback we have received from participants to date and our own impressions of it to date confirm the utility of this project stage for activists seeking to rebuild movements and spark their radical imaginations. Our hope for this stage of the project continues to be that voices from outside the Halifax community will catalyze and provoke new ideas and conversations that might otherwise not be possible. This is not because our research participants lack the necessary imagination, but because, as we discovered in our interviews, dialogue sessions, and conversations, complicated personal and political histories render some important issues and debates essentially taboo. Outside perspectives and voices may allow us to navigate fractures and fissures that otherwise might be impassable.

\section{Conclusion: Social Research, Social Change, and the Future}

At a historical moment marked by limitless crisis, war, austerity, deepening inequality, social decay, and an ever augmented repressive state apparatus, researchers and other intellectuals willing to offer ideological and technocratic fixes in defense of the dominant order and the elite interests it represents are now cast as "public" social scientists par excellence. But, as Janet Roitman (2013) has so perceptively noted, declarations of "crisis" today are not simply descriptions of empirical realities; they are invocations of the powerful that serve to open up certain pathways for action while foreclosing others. As traditional sources of funding for research and post-secondary education dry up, withered in the neoliberal desert, more and more universities, faculties, departments, and academics have felt compelled to court private, vested interests - particularly from the corporate sector-to replace them and, in so doing, have paid for their continued existence with their autonomy, integrity, and critical capacity. In this sense, the trope of crisis has served as a powerful disciplining tool reshaping the ways research, critical inquiry, and education are envisioned, valued, and practiced.

Against research as technocracy, I have attempted to chart an alternative approach to what a practice of solidarity research might look like. While it should be abundantly clear the Radical Imagination Project is far from perfect, as an experiment in innovating an ethnographically-based research method capable not only of documenting social movements and social change struggles but actually engaging them it has proven promising. More than this, our project has also demonstrated that it is possible to conduct engaged, committed research that participates in efforts to realize a better world without sacrificing academic rigour or our imperfect autonomy as researchers in so doing. Indeed, through this work we fruitfully explored the utility of the weird and always unjust autonomy of the academy as a way to do research with social movements that contributes something to them that they are not doing for themselves. In this sense, our project not only provided 
resources and neutral space for activists to have discussions they were not having elsewhere, it also intervened in the frenzied temporality of activism so frequently characterized by urgent mobilizations to defend against both the erosion of gains won and fresh attacks to the fabric of social justice. This slower space and time provided by our solidarity research, as I have discussed throughout this piece, allowed for critical moments of deep reflection and afforded the opportunity for activists to have conversations about "big ideas" that they felt they did not have the time or luxury for in the course of their day-to-day activities. This is, hopefully, not all solidarity research can do, but it is nonetheless a satisfying and useful place to start.

The systemic forms of violence, inequality, and exploitation shaping our world today will not be solved through technocratic fixes or through the proper application of expert knowledge. In fact, if the latest convulsions of global capitalism reveal anything, it is that our systems of knowledge production and application have largely become far too enmeshed in the status quo and the dominant interests it reflects. What is needed, then, at least in part, are approaches to critical research that seek not only to describe a given phenomena or to ruminate endlessly on its complexity but to participate in facilitating collective, grassroots ways of envisioning and, ultimately, materializing alternatives to systemic forms of oppression and exploitation. Critical and engaged research grounded in rigorous, principled methods matters - perhaps now more than ever given the ideological, mystifying nature of the ascendant Right's assault on basic principles of reason, justice, democracy, equality, freedom, and peace - and while it is not the only or even the most important piece in the social change puzzle, it has the potential to assist social justice struggles in ways that go beyond providing good information or reliable analysis. Today we face a concerted attempt to enclose our collective imagination of the politically possible by those with vested interests in diminishing our capacity to envision and live otherwise. In the face of this, critical social research must not only help reveal structures and systems of violence, exploitation, and oppression - as well as those who benefit from their perpetuation and those who are consumed by them; it must also contribute to people's capacity to imagine and forge paths beyond them.

\section{References}

Appadurai, A. (1996). Modernity at large: Cultural dimensions of globalization. Minneapolis: University of Minnesota Press.

Bagguley, P. (1992). Social change, the middle class and the emergence of "new social movements": A critical analysis. The Sociological Review, 40, 26-48. doi:10.1111/j.1467954X.1992.tb02944.x

Bandy, J., \& Smith, J. (Eds.). (2005). Coalitions across borders. Lanham, MD: Rowman \& Littlefield.

Benford, R., \& Snow, D. (2000). Framing processes and social movements: An overview and assessment. Annual Review of Sociology, 26, 611-639.

Bishop, A. (2002). Becoming an ally: Breaking the cycle of oppression in people. Halifax, NS: Zed Books and Fernwood Publishing.

Bockmeyer, J. (2003). Devolution and the transformation of community housing activism. The 
Social Science Journal, 40, 175-188. doi:10.1016/S0362-3319(03)00002-8

Clifford, J., \& Marcus, G. (Eds.). (1986). Writing culture: The poetics and politics of ethnography. Berkeley: University of California Press.

Conway, J. (2004). Identity, place, knowledge: Social movements contesting globalization. Halifax, NS: Fernwood.

Day, R. (2005). Gramsci is dead: Anarchist currents in the newest social movements. Toronto: Between the Lines.

Day, R., De Peuter, G., \& Coté, M. (Eds.). (2007). Utopian pedagogy: Radical experiments against neoliberal globalization. Toronto: University of Toronto Press.

Della Porta, D., Kriesi, H., \& Rucht, D. (2009). Social movements in a globalizing world. Basingstoke: Palgrave Macmillan.

Epstein, B. (1991). Political protest and cultural revolution nonviolent direct action in the 1970s and 1980s. Berkeley: University of California Press.

Featherstone, D. (2012). Solidarity: Hidden histories and geographies of internationalism. London; New York: Zed Books.

Federici, S. (2003). Caliban and the witch : Women, the body and primitive accumulation. New York; London: Autonomedia ; Pluto.

Federici, S. (2012). Revolution at point zero: Housework, reproduction, and feminist struggle. Oakland, CA: PM Press.

Goodwin, J., Jasper, J., \& Polletta, F. (2001). Passionate politics: Emotions and social movements. Chicago: University of Chicago Press.

Graeber, D. (2007). Possibilities: Essays on hierarchy, rebellion, and desire. Edinburgh: AK Press.

Graeber, D. (2009). Direct action: An ethnography. Oakland: AK Press.

Haiven, M., \& Khasnabish, A. (2010). What is radial imagination? A special issue. Affinities: A Journal of Radical Theory, Culture, and Action, 4(2), i-xxxvii.

Haiven, M., \& Khasnabish, A. (2013). Between success and failure: Dwelling with social movements in the hiatus. Interface: A Journal for and about Social Movements, 5(2), 472 498.

Hardt, M., \& Negri, A. (2004). Multitude: War and democracy in the age of empire. New York: The Penguin Press.

Harvey, D. (2003). The New Imperialism. Oxford: Oxford University Press.

Haworth, R. H. (Ed.). (2012). Anarchist pedagogies: collective actions, theories, and critical reflections on education. Oakland, CA: PM Press.

Hedges, C. (2010). The death of the liberal class. Toronto: Alfred A. Knopf Canada.

Holloway, J. (2002a). Change the world without taking power: The meaning of revolution today. London: Pluto Press.

Holloway, J. (2002b). Zapatismo and the social sciences. Capital \& Class, 78, 153-160.

Jasper, J. (1999). The art of moral protest: Culture, biography, and creativity in social movements. Chicago: University of Chicago Press.

Juris, J. S. (2007). Practicing militant ethnography with the movement for global resistance in Barcelona. In D. Graeber \& S. Shukaitis (Eds.), Constituent imagination: militant investigations, collective theorization. Oakland: AK Press.

Juris, J. S. (2008). Networking futures: The movements against corporate globalization. Durham: Duke University Press.

Juris, J. S., \& Khasnabish, A. (Eds.). (2013). Insurgent encounters: Transnational activism, ethnography, and the political. Durham; London: Duke University Press.

Katsiaficas, G. (1987). The imagination of the New Left: A global analysis of 1968. Boston: South End Press.

Katsiaficas, G. (2006). The subversion of politics : European autonomous social movements and the decolonization of everyday life. Edinburgh: AK Press.

Keck, M., \& Sikkink, K. (1998). Activists beyond borders: Advocacy networks in international politics. Ithaca: Cornell University Press.

Keefer, T. (2007). The politics of solidarity: Six Nations, leadership, and the settler left. Upping the Anti: A Journal of Theory and Action, 4, 107-123.

Khasnabish, A. (2008). Zapatismo beyond borders: new imaginations of political possibility. Toronto: University of Toronto Press.

Khasnabish, A., \& Haiven, M. (2012). Convoking the Radical Imagination: Social Movement 


\section{Alex Khasnabish}

Research, Dialogic Methodologies, and Scholarly Vocations. Cultural Studies \&\#x2194; Critical Methodologies, 12(5), 408-421. doi:10.1177/1532708612453126

Klein, N. (2008). The shock doctrine: The rise of disaster capitalism. Toronto: Vintage Canada.

Lal, V. (2002). Empire of knowledge: Culture and plurality in the global economy. London; Sterling, Va.: Pluto Press.

Lowry, M., \& Nyers, P. (2003). Roundtable report "no one is illegal": The fight for refugee and migrant rights in Canada. Refuge, 21(3), 66-72.

Maeckelbergh, M. (2009). The will of the many. London: Pluto Press.

Mansbridge, J., \& Morris, A. (Eds.). (2001). Oppositional consciousness: The subjective roots of social protest. Chicago: University of Chicago Press.

Martinez, E. B. (2000, March 10). Where Was the Color in Seattle? Looking for reasons why the Great Battle was so white. Colorlines. Retrieved June 10, 2013, from http://colorlines.com/ archives/2000/03/where_was_the_color_in_seattlelooking_for_reasons_why_the_great_ battle_was_so_white.html

McCready, A. L. (2013). Yellow ribbons: The militarization of national identity in Canada. Halifax, Nova Scotia: Fernwood Publishing.

McKay, I. (2005). Rebels, reds, radicals: Rethinking Canada's left history. Toronto: Between the Lines.

McNally, D. (2011). Global slump: The economics and politics of crisis and resistance. Oakland: PM Press.

Melucci, A. (1985). The symbolic challenge of contemporary movements. Social Research, 52(4), 789-816.

Meyer, D. (2004). Protest and political opportunities. Annual Review of Sociology, 30, 125-145. doi:10.1146/annurev.soc.30.012703.110545

Mies, M. (1986). Patriarchy and accumulation on a world scale: Women in the international division of labour. London: Zed Books.

Mohanty, C. T. (2003). Feminism without borders: Decolonizing theory, practicing solidarity. Durham: Duke University Press.

Network of Concerned Anthropologists (Ed.). (2009). The counter-counterinsurgency manual : Or, notes on demilitarizing American society. Chicago, IL: Prickly Paradigm Press.

Osterweil, M. (2010). "Becoming-Woman?" In theory or in practice. In Turbulence Collective (Ed.), What would it mean to win? (pp. 82-89).

Polletta, F. (2002). Freedom is an endless meeting : democracy in American social movements. Chicago: University of Chicago Press.

Price, D. H. (2011). Weaponizing anthropology : Social science in service of the militarized state. Edinburgh: AK Press.

Roitman, J. L. (2013). Anti-crisis. Durham: Duke University Press.

Selbin, E. (2010). Revolution, rebellion, resistance: The power of story. London; New York: Zed Books.

Sinclair, S., \& Jacobs, J. (2007). Atlantica myths and realities. Ottawa: CCPA.

Sitrin, M. (2012). Everyday revolutions: Horizontalism and autonomy in Argentina. London; New York: Zed Books.

Smith, J. (2008). Social movements for global democracy. Baltimore: Johns Hopkins University Press.

Smith, L. (1999). Decolonizing methodologies: Research and indigenous peoples (1. publ.). London: Zed Press.

Solnit, D. (Ed.). (2004). Globalize liberation: How to uproot the system and build a better world. San Francisco: City Lights Books.

Tarrow, S. (1988). National politics and collective action: Recent theory and research in Western Europe and the United States. Annual Review of Sociology, 14, 421-440.

Touraine, A. (1988). Return of the actor: Social theory in postindustrial society. Minneapolis: University of Minnesota Press.

Turbulence Collective. (2010). What would it mean to win? Oakland, Calif: PM Press.

Wachsmuth, D., \& Pasternak, S. (2008). Use it or lose it: Toronto's "Abandonment issues" campaign for affordable housing. Critical Planning, 15, 7-21.

Walia, H. (2013). Undoing border imperialism. Oakland, CA: AK Press.

Wallerstein, I. (1996). Open the social sciences: Report of the Gulbenkian Commission on the Restructuring of the Social Sciences. Stanford, CA: Stanford University Press. 
Wood, L. J. (2012). Direct action, deliberation, and diffusion: Collective action after the WTO protests in Seattle. Cambridge: Cambridge University Press.

Zald, M., \& McCarthy, J. (Eds.). (1979). The dynamics of social movements: Resource mobilization, social control, and tactics. Cambridge, MA: Winthrop. 